Okur, Hüseyin (2020). “Hicri Birinci Asırda Fıkhın Tedvîni ve Fuat Sezgin'in Tespitleri Üzerine Bir İnceleme". Uludağ Üniversitesi Fen-Edebiyat Fakültesi Sosyal Bilimler Dergisi, C. 21, S. 39, s. 957-982.

DOI: $10.21550 /$ sosbilder.659516 Araştırma Makalesi

\title{
HİCRİ BİRINCİ ASIRDA FIKHIN TEDVÎNİ VE FUAT SEZGIN'İN TESPİTLERİ ÜZERİNE BİR İNCELEME
} Hüseyin OKUR*

Gönderim Tarihi: Aralık 2019

Kabul Tarihi: Nisan 2020

\section{ÖZET}

İslam hukuk literatürüne dair günümüze ulaşan eserler, müstakil mezheplerin kuruluş dönemine denk gelen hicri II. asrın ortalarından itibaren görülmeye başlanmıştır. Hicri I. asırda telif edildiği bilinen ve sonraki döneme kaynakllk ettiği düşünülen eserler ise oldukça sınırlıdır. Bu dönemde telifatın az olmasının önemli sebepleri arasında, ilmi faaliyetlerin ve eğitim-ögretimin daha ziyade şifahî gelenek yoluyla mümkün olabileceğine ve bu dönemde kitap telif etmenin bazı sakıncalarının bulunduğuna dair kanaatlerin bulunmasıdır. Tabi bu durumun sosyal ve ekonomik sebepleri de yok değildir. Ayrıca bu dönemde yaşayan bazı müelliflerin kitap yazımı hakkındaki kişisel kanaatleri de telif faaliyetlerinin kemiyetinde etkili olmuştur. Bu çalışmada fikıh ekollerinin kuruluş aşaması olan H II. asra ait bilinen derlemelerin öncesindeki mevcut fiklh literatürüne genel bir bakış hedeflenmiş ve bu döneme ait yazınsal faaliyetler hakkındaki Fuat Sezgin'in tespitleri incelenmiştir.

Anahtar Kelimeler: İslam Hukuku, hukuk tarihi, hicri I. asır, tedvin, Fuat Sezgin

Dr. Öğr. Üyesi, Kocaeli Üniversitesi İlahiyat Fakültesi Temel İslam Bilimleri Bölümü Fıkıh Ana Bilim Dalı, huseyin.okur@kocaeli.edu.tr

Uludağ Üniversitesi Fen-Edebiyat Fakültesi Sosyal Bilimler Dergisi Uludağ University Faculty of Arts and Sciences Journal of Social Sciences

Cilt: 21 Sayı: 39 / Volume: 21 Issue: 39 


\title{
An Analysis on The Notation Fiqh in the First Century of Hijrah and Fuat Sezgin's Findings
}

\begin{abstract}
The works belonging to Islamic law literature that have made it to our day are the ones that have started to emerge from the middle of the second century after Hijrah. The number of works that are known to have been authored in the first century after Hijrah and believed to have served as a source for the coming periods is very limited. Among the reasons for the low number of authored works in this period are certain opinions maintaining that scholarly activities and education were only possible when conducted in person, as was the tradition, and that authoring works in this period had its own complications. Of course, it wouldn't be an extrapolation to say that there weren't any social or economic reasons for this. In addition, certain personal opinions belonging to some authors who lived in this period regarding the writing of such works have had an effect on the quantity of written works. This study aims to present an overview of the existing fiqh literature predating known compilations done in the second century after hijrah, which is known as the founding stage of the schools of fiqh, and examine Fuat Sezgin's findings on textual activities in this period.
\end{abstract}

Key words: Islamic Law, history of law, first century after hijrah, notation fiqh, Fuat Sezgin

\section{Giriş}

Kanunlaştırmanın biri genel diğeri ise özel olmak üzere iki anlamı bulunmaktadır. Genel anlamda kanunlaştırmadan, kanun hâlinde kurallar koyma, yani kanun yapma (taknîn- legislation) anlaşılır. Özel anlamda kanunlaştırma ise, mahalli hukuku birleştirme gayesiyle ve hukukun belirli bir kolu ile ilgili olmak üzere mevcut hukuk kurallarını kanun şeklinde derleme (tedvin-codification) demektir (Kılıç 2008: 1). İslam hukukunda fikhî hükümlerin şekilsel olarak kanunlaştırılması geç denecek bir dönemde gerçekleşmiş olmakla birlikte, fikhın hemen hemen her alanına dair hukuk kurallarının yazımı, İslam'ın ilk dönemlerinde dağınık bir şekilde bulunan yazılı ve sözlü hukukî metinlerinin bir araya getirilerek düzenlenmesiyle başlamıştır. 
Fıkıh ilmine kaynaklık eden ve İslam hukukunun ikinci kaynağ olan Hz. Peygamber'in sünnetinin daha ilk dönemlerden itibaren yazıya geçirilmeye başlandığı hakkında artık bir kapalılık bulunmamaktadır. Sistematik bir şekilde sünnetin kitaplara geçirilmesi (tasnif) ise fıkıh eserlerinde olduğu gibi hicri II. asrın ortalarından itibaren başlamıştır. Bununla birlikte Buhârî'nin Sahîh'i ve Müslim'in Sahîh'inin ilim bölümleri ile benzeri kaynaklarda, Hz. Peygamber'in hayatının sonlarına doğru hadisleri yazma izni verdiğini gösteren açık ve güçlü ifadeler mevcuttur. Süleyman Nedvî, M. Hamidullah, Fuat Sezgin gibi âlimlerin araştırmaları, hadislerin çok erken bir zamanda yazılmaya başlandığını; Buhârî, Muvatta' gibi önemli hadis kaynaklarının sözlü rivayetler yanında yazılı rivayetlere de dayandığını ortaya koymuştur. Sezgin'in kanaatleri ilk dönem; sahabe ve tabiin dönemlerinde, hadislere ait sahifelerin yanında fikha dair risale türü yazılı materyallerin bulunduğu yönündedir. Ona göre, müstakil ve sistematik mezhepler döneminde olduğu gibi hacimli ve konularına göre düzenlenmiş fikıh kitapları gibi olmasa da bu dönemde fikıh yazımı başlamıştır.

\section{Hicri Birinci Asırdaki Tedvin Faaliyetlerinin Oluşum ve Gelişimine Genel Bir Bakış}

İslam'ın erken dönemlerinin yazılı metinleri hakkında çok fazla bilgi sahibi olmadığımız bir gerçektir. Hz. Peygamber'in vefatından itibaren Ebu Hanife'nin, vefat eden hocas1 Hammâd b. Ebû Süleyman'ın (öl. 120 / 738) kürsüsünde ders vermesine kadarki dönem aralığı şeklinde tarif edebileceğimiz ve İslam hukukunun kuruluş asrı olarak tanımlayabileceğimiz bu zaman dilimi içinde tedvin faaliyetlerinin neden gelişmediği yahut yapılmadığ hakkında pek çok sebepten bahsedilebilir. İslam'ın erken döneminde tedvin faaliyetinin çok sınırlı oluşu hakkında bazı gerekçeler ileri sürülmüştür. Örneğin Kâtib Çelebi'nin (öl. 1067 / 1657), bu dönemde tedvin faaliyetinin olmayışı hakkında bazı değerlendirmeleri bulunmaktadır. Ona göre Hz. 
Peygamber'in risaleti ile birlikte her konuda dağınık bir hâlde bulunan cahiliye Arapları bir araya gelmiş, inanç, amel ve birlikte yaşama hususlarında ittifak etmişlerdir. Hz. Peygamber'in aralarında az bir zaman kalıp vefat etmesinin ardından sirasıyla sahabeleri onun halefi olmuştur. Çok kısa bir zaman içerisinde mülk ve hükümranlığa kavuşmuşlardır. İslam devletinin sınırları Fars, Irak, Horasan, Şam, Mısır'a kadar genişlemiştir. Araplar, İslam'ın ilk yıllarında gerek edebî ve tarihi ilimlerin gerekse şer'î ilimlerin şifahî yolla aktarımına ehemmiyet vermişler hatta şer'î meselelerin yazımı bir yana ancak ihtiyaç hâsıl oldukça üzerinde konuşulması gerektiğini düşünmüşlerdir. Bunu, İslam'ın amelî ve itikadî prensiplerinin korunması düşüncesiyle yapagelmişlerdir. Hatta fethedilen bölgelerdeki kitaplar yakılmış, Kur'an ve sünnet etrafında toplanmayı sağlayabilmek için Tevrat ve İncil'in okunması yasaklanmıştır. Bu durum tâbiîn dönemine kadar devam etmiştir. Tâbiîn döneminden başlayarak ilerleyen süreç içinde ve İslam topraklarının kozmopolit bir yapıya bürünmesiyle birlikte, kültürel, ekonomik ve sosyal sebeplere bağlı olarak pek çok farklı ve yeni görüş ortaya çıkmış ve buna paralel olarak da mezhepler intişar etmiştir. $\mathrm{Bu}$ yeni gelişmeler ister istemez tedvin faaliyetlerinin başlamasına neden olmuştur (Kâtib Çelebi 1941: 1 / 34).

Kâtib Çelebi'ye göre sahabe döneminde henüz tedvin faaliyetlerinin başlamamasının sebebi, sahabe döneminde fikhî ve itikadî ihtilafların, sonraki dönemlere nazaran daha az olması, olsa bile problemlerin çözümü için kendilerine güvenilecek ehil kişilere ulaşılabilme imkânının bulunmasıdır. $\mathrm{Bu}$ sebeple sahabe, şer'î hükümlerin tedvinine ihtiyaç duymamıştır. Hatta Kâtib Çelebi'ye göre bu dönemde şer'î / ilmî bilginin yazılmasını kerih görenler bile olmuştur. $\mathrm{Bu}$ meyanda zikrettiği rivayetlerden birine göre adamın biri Abdullah b. Abbâs'a gelerek, "Bir kitap yazdım bunu size göstermek istiyorum" demiştir. İbn Abbâs kitaba baktıktan sonra suya atarak telef etmiştir. Kendisine bunu neden yaptığı sorulunca, "Çünkü onlar [bu tür bilgileri] kitaplaştırdıkları zaman sadece kitaplarda yazılanlarla 
yetinecekler, bilgiyi ezberlemeyi bırakacaklar sonra bu kitaplarda bir takım değişiklikler meydana gelecek ve onların tüm amelleri zayi olacak" şeklinde cevap vermiştir. Kâtib Çelebî’ye göre o dönemde kitap yazımındaki endişelerin temel sebebi, kitap çoğaltma ameliyesinin istinsah faaliyeti sebebiyle yürümesi ve bu sebeple ibareler arasına anlamı ve maksadı değiştirecek ilaveler ve çıkarmalar yapılmasının kolay olmasıdır. Fakat zaman ilerleyip İslam yayılmaya başlayınca, şehirler büyüyüp sahabeler farklı bölgelere dağılınca ve fitne / kargaşalar artıp görüş ayrılıkları ortaya çıkınca ve buna bağlı olarak fetvalar artınca ilim ehli hadis, fikıh ve Kur'an ilimlerinin tedvinine başlamışlardır. İlk zamanlar hoş karşılanmayan tedvin faaliyeti, sonraları maslahat sebebiyle güzel görülmüş ve teşvik edilmiştir (Kâtib Çelebi 1941: 1 / 34-35).

İlk dönemdeki tedvin faaliyetinin hadis ve fikı eksenli olduğunu göz önünde bulundurduğumuz zaman, hadis literatüründe zikredilen hadislerin yazılmasına karşı ileri sürülen rivayet ve anekdotlar, hadislerin yazılmasına karşı değil, bilakis kitâbe yoluyla nakledilmesine karşı olmuştur. Bu da ilim aktarma usul ve geleneğinin yani icazet yolunun şifahî geleneğe uygunluğundan kaynaklanmaktaydı. İşte bu gerekçeye dayanarak, menşei çok eskilere dayandığı ifade edilmekle beraber, İslam kültüründe de mevcut olan kitap yakma geleneğinin, bilginin kitaplardan değil; hoca talebe ilişkisi ve rahle-i tedris yoluyla alınması yönündeki baskın düşünce sebebiyle yapılageldiği düşünülmektedir. $\mathrm{Bu}$ meyanda rey' ekolünün ilk temsilcilerinden sahabe Abdullah b. Mesud'un (öl. 32 / 652-53) öğrencilerinden Abîde es-Selmânî'nin (öl. 72 / 691) ölmeden önce kitaplarının yakılmasını istemesi ve buna gerekçe olarak da kitaplarının yanlış anlaşılabileceğini öne sürmesini örnek kabilinden zikredebiliriz. Rivayetlere göre es-Selmânî, ölmeden önce kitaplarının getirilmesini istemiş, sonra onları imha ettirmiştir. Sebebini soranlara gerekçe olarak da, "Bu kitaplarda yazılanları yerli yerinde kullanamazsınız" demiştir (Zehebî 1985: 4 / 44). İlk dönemlerde yaygın olan kitap imha 
geleneğinin, kitapların ehil olmayanların eline geçmesinden, dolayısıyla yazılanların mahiyetini anlamadan yorum yapılması endişesinden ötürü uygulandığı biliniyordu. Nitekim İbn Sad'ın rivayeti bu manayı doğrular mahiyettedir. Onun naklettiğine göre Abîde ölmeden önce, "Benden sonra birileri gelir ve bu kitaplarda olanları zayi eder" demiştir (İbn Sa'd 1990: 6/153). Hilmi Demir'e göre İslam düşüncesinde ezbere dayalı şifahî gelenek ile yazı arasındaki bu gerilim, yaklaşık hicri yüz ellili yıllara kadar devam etmiştir. Ona göre bu dönemde tedvin faaliyetine yeterli eğilimin gösterilmemesinin temel nedeni, sözlü düşünüş karşısında yazılı olanın anlamsal bir değerinin olmadığına ilişkin kabuldür (Demir 1998: 143).

Sezgin'in düşünceleri de bu kanaati destekler mahiyettedir. $\mathrm{O}$, Ignaz Goldziher ve Carl Brockelmann gibi şarkiyatçıların eserlerinde zikrettikleri, Urve b. Zübeyr' in sahip olduğu birçok fikıh kitabının, Medineliler ile Emevî kuvvetleri arasında Harretüvâkım'da (Harre Günü) cereyan eden savaşta alevlerin kurbanı olması hakkında rivayeti (İbn Sa'd 1990: 5 / 133) ve bu rivayet hakkındaki, o dönemde gerçek anlamda kitaplardan söz edilemeyeceği ve bunların sadece bazı önemsiz notlardan ibaret oldukları iddiasıyla, bu haber ve benzerlerine çok da önem verilmemesi gerektiği şeklindeki yorumlarını (Goldziher 1967: 2 / 108; Brockelmann 1937-1942: 1 / 282) eleştirmektedir (Sezgin 1991: 1/3/393). Goldziher'e göre, gerek şifahî gelenek gerekse yazılı metinler vasitasıyla, sistematik tedvin dönemine kadar gelen hadis ve diğer rivayetlerin $\mathrm{Hz}$. Muhammed'le doğrudan bir ilgisi yoktur. Bu rivayetler, İslâm'ın birkaç asır devam eden oluşum süreci içinde bu sürece katılan siyasî, içtimaî, iktisadî vb. birçok faktör sebebiyle oluşmuştu. Bu sebeple Goldziher'e göre fikhın kodifikasyonunun bu dönemde başlamış olması imkânsızdı (Goldziher 1967: 2 / 5).

Sezgin'e göre, İslam'in erken dönemine ait metinlerin sonraki dönemlere ulaşmadığı söylemi, modern araştırmalarda sıç̧a tekrar edilen, İslâm tarihinin erken devrine ait metinler hakkındaki haberlerin tipik bir yorumudur. Ancak diğer alanlarda, bu tür haberlerin 
doğruluğunun kesin bir şekilde reddedilmesinden henüz sakınılması gerekmektedir (Sezgin 1991: 1/3/393).

İlk dönemlerde hadis yazımı ile fikıh yazımı arasında sinırları net çizilmiş bir ayrım belirlemek zordur. Zira bu dönemlerde fikıh daha çok rivayetlerin nakli şeklinde seyrediyor ve rivayetlerin çoğu da hadis olarak naklediliyordu. Hadislerin yazımı hakkındaki tereddütler ve bu meyandaki yasaklamalar muhtemelen fikhın yazımını da etkilemiştir. Nitekim Sezgin, bu döneme ait özellikle fikıh kodeksinin, günümüze ulaşabilen malzemenin eksikliğinin, bu alanla ilgili elimizde bulunan en eski kitaplardaki rivayet zincirleri tetkik edilerek bir ihtimal telafi edilebilir, düşüncesindedir. Çünkü müstakil müçtehitler döneminden itibaren kaleme alınmaya başlanan başta Muvatta' olmak üzere diğer musannef türü eserlerdeki İslam'in ilk dönem müelliflerine, isimli ya da isimsiz yapılan atıflar ve bu döneme ait kayıp kitapların bölümleri, bu risalelerin kısmen de olsa muhafaza edilmesini sağlamıştır (Sezgin 1991: 1/3/394).

Hicri I. asırdaki tedvin faaliyetini zorlaştıran bir diğer unsur da, bu dönemde mevcut olan yazı malzemesinin tedvini elverişsiz kılacak kadar yetersiz veya az bulunmasıdır. Nitekim Abbasîler döneminde kitap telifinin kolay ve yaygın olmasının arka planında, devlet desteğinin yanı sıra dönemin önemli devlet adamlarından Fazl b. Yahya el-Bermekî'nin (öl. 193 / 808), Horasan valiliği sırasında (176 / 792) Semerkant'taki kâğıt imalâthanesini gördükten sonra bunun bir örneğini Bağdat'ta kurdurmas1, kitap telifinin ilerlemesinde önemli rol oynamıştır (Brockelmann 1942: 1 / 308).

Bazı İslam tarihçileri, hicri I. asrın sonları ile II. asrın ortalarına doğru yaşamış bazı fakih ve muhaddislerin, ilk kitap tedvin eden kişiler olduğunu söylemek suretiyle, tedvin faaliyetinin başlangıcının daha geç başladığını söylemişlerdir. Bu rivayetlerden etkilenmiş olacaklar ki, son dönem bazı İslam hukuk tarihi araştırmacıları bu söylemlerden etkilenmişler ve ilk dönemde yazınsal faaliyet olmadığı kanısına varmışlardır. Örneğin Hatîb el-Bağdâdî (öl. 463 / 1071), Abdülmelik b. 
Abdilazîz b. Cüreyc el-Kureşî’nin (öl. 150 / 767) tercüme-i hâlinden bahsederken onun İslâm tarihinde kitap yazan ilk müellif olduğu söylenmiştir (Hatîb el-Bağdâdî 1417: 10 / 399). Sezgin bunun doğru olmadığını ileri sürmüştür (Sezgin 1956: 41-42). Aynı şekilde Basralı fakih ve muhaddislerden İbn Ebû Arûbe'nin de (öl. 156 / 773) ilk kitap telif eden kişi olduğu rivayet edilmiştir (Dârekutnî 1985: 12 / 246). Hadis tarihinde önemli bir yeri olan İbn Ebû Arûbe'nin, kendisine ulaşan sözlü ve yazılı rivayetleri fikıh baplarına göre Basra'da (veya Hicaz'da) ilk defa tasnif ettiği söylenen iki kişiden biridir. Hicri II. (VIII) asrın ilk yarısında ortaya konulan ve "sünen" adıyla bilinen bu tür hadis mecmualarının ilk örneği kabul edilen eserini (İbn Nedîm 1997: 283) İ̉bn Ebû Arûbe'nin, yazılı metne bakmadan hıfzından rivayet edebildiği kaydedilir. Goldziher, ilk dönem tedvin faaliyetleri hakkında şüpheli yaklaşımını İbn Ebû Arûbe hakkında da ileri sürmüştür (Goldziher 1970: 2 / 196-197) Ancak Sezgin, onun herhangi yazılı bir esere bakmadan telif yapmasının bir çelişki oluşturmayacağını zira İbn Ebû Arûbe'nin çok güçlü bir hafizaya sahip olduğunu belirtmiştir (Sezgin 1956: 38-42, 45, 205, 207).

Bu iki kişiden başka kaynaklarda İslam'da ilk kitap telif ettiği bildirilen başka isimler de göze çarpmaktadır. Örneğin Rebî‘ b. Sübeyh (öl. 160 / 777) Süfyân b. 'Uyeyne (öl. 198 / 814), Mâlik b. Enes (öl. 179 / 795), Abdullah b. Vehb (öl. 197 / 813), Ma'mer b. Râşid (öl. 153 / 770), Abdürrezzâk es-San'ânî (öl. 211 / 826-27), Süfyân es-Sevrî (öl. 161 / 778), Muhammed b. Fazl b. Gazvân (öl. 195 / 810), Hammâd b. Seleme (öl. 167 / 784), Ravh b. Ubâde el-Basrî (öl. 205 / 820), Hüşeym b. Beşîr el-Vâsitî (öl. 183 / 799), Abdullah b. Mübârek el-Mervezî (öl. 181 / 797) gibi tebe-i tâbiînin önde gelenleri, ilk eser tedvin edenler arasında sayılmıştır (Sıddik Hasan Han 1978: 1 / 178; Ziriklî 2002: 4 / 217). Fakat kaynaklarda zikredilen bu müelliflere nispet edilen eserler daha çok mevcut materyali toplama ve hadisleri konularına göre tasnif etme biçiminde bir tedvin faaliyeti olduğundan mevcut materyali toplayıcı, derleme eserler olarak kabul edilmesi daha doğru olur. Ayrıca 
bu müellifler ve eserleri, hicri I. asırda telif edildiği kesin olarak bilinen fikhî çalışmalara göre çok uzak bir zaman diliminde durmaktadır.

\section{Fuat Sezgin'in Tespitlerine Göre Erken Dönem Fıkıh Çalışmaları}

Erken döneme ait fikıh metinlerinin varlığı kesin olarak bilinmekle birlikte bu döneme nispet edilen eserler, sonraki döneme ait kitaplarla aynı kapsam ve tertibe sahip değildir. Sezgin'in ifadelerine göre İslam'ın bu erken dönemine ait kısa metin, risale ve mektup tarzı yazınlar, o zamanki anlayışa göre kitap idi ve böyle isimlendirilmişlerdi. Elde mevcut veriler çok sınırlı da olsa o dönemden günümüze kadar gelebilmiş bazı kitaplar sayesinde, bu fikıh çalışmalarını tanımak mümkün olabilmiştir (Sezgin 1991: 1/3/394).

İlk dönem fikhın tedvinini net bir şekilde görebilmek için sahabe ve tabiin dönemlerinin arasını ayırmak zamansal olarak mümkün olsa da fertlerin İslam'a giriş dönemleri, sahabe kavramına yüklenen anlam, sahabenin uzun süre tâbiînle beraber olmaları, tâbiînden pek çoğunun dini bilgi birikimi olarak bazı sahabelerden daha iyi durumda olmaları gibi sebeplerle ilk dönem tedvin faaliyetini bu iki nesil ile beraber zikretmek yerinde olacaktır. Zira sahabe döneminin başlangıcı $\mathrm{Hz}$. Peygamber'in vefatıyla başlayıp hicri I. asrın sonlarına kadar devam etmekte ve yine ayn yüzyıl içinde hem küçük sahabelerin hem de tâbiînin döneminden söz edilmektedir. Ancak şunu söyleyebiliriz ki, İslam hukukuna ait dağınık şekilde bulunan yazılı ve yazısız hukuk kurallarının bir araya getirilerek bir sistem içinde düzenlenmesi ve belli alanları düzenleyen kapsamlı ve büyük fikıh eserlerinin hazırlanması, ancak hicri II. asrın başlarında, İslami hükümlerin geliştirilmesinde kendi yöntem ve yöntemlerine sahip müçtehitler vasıtasıyla mümkün olabilmiştir.

Modern dönemde yazılan İslam hukuk tarihi eserlerinde fikhın geçirdiği evreler içinde hicri I. asrı içine alacak şekilde sahabe ve tabiin dönemi genellikle oluşum dönemi olarak adlandırılmıştır. Örneğin 
Abdülvehhab Hallâf' 'n (öl. 1956) tasnifinde fikıh tekvin, tefsir, tedvin ve taklit olarak dört ana döneme ayrılmış ve tekvinin Hz. Peygamber (s.a.v), tefsirin sahabe, tedvinin ise müçtehit imamlar ve öğrencileri döneminde gerçekleştiği belirtilmiştir (Hallâf 7-8). Ancak Sezgin'in ortaya koyduğu deliller, fikhın sözel bir kültür deviniminin yanında yazılı materyaller hâlinde mevcudiyetinin sahabe dönemine kadar indiğini göstermektedir. Daha önce de ifade ettiğimiz üzere Sezgin müsteşriklerin 1srarla bu dönemde tedvin yapılmadığ 1 hakkındaki söylemlerini isabetsiz bulur.

Hadis ve fikhın yazılı kaynaklarının düşünülenin aksine İslam'ın ilk dönemlere kadar ulaştığını söyleyen Sezgin'e göre Hz. Peygamber ve ashabının döneminde bile fikhî meselelere dair yazılı kayıtlar bulunmaktaydı. Zira Emevî halifesi Ömer b. Abdülazîz (öl. 101 / 720), halife olunca, Hz. Peygamber'in imla ettirdiği zekât malları ve nisaplarıyla alakalı Kitâbu's-Sadakât'ını ve Ömer b. el-Hattâb'ın aynı başlıklı metnini bulması için Medine'ye birini göndermiş, nihayet bu iki eser Amr b. Hazm el-Hazrecî'nin (öl. 53 / 673 [?]) evinde bulunmuştur. Ömer b. Abdülaziz her ikisinden de kendisi için bir kopya yapılmasını emretmiştir. Aynı dönemlerde bu kitapların başkaları için de çoğaltıldığı kaynaklarda zikredilmektedir (bkz. Ebû Ubeyde 1/ 447; İbn Zenceveyh 1986: 2 / 798). Resûlullah'ın (s.a.v) imla ettirdiği bu metnin bir kısmını Serahsî eserinde zikretmiştir. Buna göre Ebû Bekir b. Muhammed b. Amr b. Hazm, Resûlullah'in dedesine (Amr b. Hazm) (öl. 120 / 737) yazdırdığı bu risaleyi ensarın ileri gelenlerinden biri olan Kays b. Sad'a (öl. 60 / 680) göstermiştir (bkz. Serahsî 2000: 2 / 152). Sonraları Ebû Dâvud (öl. 275 / 889), Nesâî (öl. 303 / 915), İbn Hibbân (öl. 354 / 965) ve Dârimî (öl. 255 / 869) gibi müelliflerin kanonik mecmualarında da yer verilen bu mektupta (risale), ferâiz, zekât ve diyât gibi meselelerden bahsedilmektedir. Bu mektup sirasıyla Amr b. Hazm'ın oğlu ve torunu tarafindan nakledilmiştir (İbn Hacer 1415: 4 / 511; Sezgin 1991: 1/3/394). 
Enes b. Mâlik'in, Hz. Peygamber'in ferâiz ve sadaka (zekât) hakkında emirlerinin bulunduğu bir mektubu halife Ebû Bekir'den aldığ 1 da rivayet edilmektedir (Sezgin 1991: 1/3/394). Ahmed b. Hanbel'in Müsned'inde geçtiği şekliyle Hammâd b. Seleme, elindeki risaleyi etrafındakilere göstererek, "Ben bunu Sümâme b. Abdullah b. Enes'ten, o da Enes b. Mâlik'ten almıştır. Ona ise Ebû Bekir yazdırmıştır" demiştir. Risalede zekâtın Allah'ın emri olduğundan, farz olduğu şekliyle kendisine vacip olanların bunu vermesi gerektiğinden söz edildikten sonra detaylı bir şekilde develerin ve koyunların nisap miktarlarına yer verilmektedir (Ahmed b. Hanbel 2001: 1 / 232).

$\mathrm{Bu}$ döneme ait Sezgin'in tespitlerinden biri de özellikle yazı malzemesinin azlığından dolayı fikhî malzemenin kayda geçirilmesinde çeşitli yolların denenmesidir. Dolayısıyla fikhî hükümleri ihtiva eden hadis ve haberler, yazı yazılabilecek her türlü malzeme üzerine işlenerek kayıt altına alınmaya çalışılmıştır. Fakat bu tür materyallerin kitap gibi olmaması sebebiyle özel korumaya alınamamıştır. Örneğin Halife Ömer'in torunu, dedesinin vefatından sonra kılıcının kabzasında, merada beslenen hayvanların vergilendirilmesi hakkındaki bir sahife bulduğunu haber vermektedir (Hatîb el-Bağdâdî, el-Kifâye: 1 / 353, Sezgin 1991: 1/3/395).

$\mathrm{Bu}$ dönemde kılıcın kınına ya da kabzasına yazılı materyal koymak, saklanması ve uzun süre muhafaza edilmesini sağlamak açısından tercih edilen bir yol olmuştu. Kufeli tâbiînden Târık b. Şihâb, Hz. Ali'nin bir hutbesinde şöyle dediğini aktarmıştır: "Bizim yanımızda okuduğumuz Allah'ın kitabı vardır. Şu elimde tuttuğum sahifeleri ise bizzat Resûlullah'tan aldım. Bunda zekât malları ile nisapları ve ferâize dair meseleler vardır." Bu risale Hz. Ali'nin yanında taşıdığ 1 kılıcın kabzasinda muhafaza ediliyordu (Ahmed b. Hanbel 2001: 2 / 170, 181, 221, 269)

İslam'in erken dönemlerinde Hz. Peygamber'in ve hulefa-i raşidinin hukuki mahiyetli söz ve emirlerinin sahifeler hâlinde yazılı olduğunu görüyoruz. Bu manada Hatîb el-Bağdâdî’nin, el-Kifâye fî 
ilmi'r-rivâye adlı eseri incelenebilir. Sezgin'in naklettiğine göre, Hz. Alî'nin oğlu İbn el-Hanefiyye (öl. 81 / 700) bir defasında babasının kendisine bir yazı verip şöyle dediğini bildirmektedir: "Bunu al ve Osman'a götür. Onda, Hz. Peygamber'in sadaka hakkındaki emirleri bulunmaktadır" (İbn Hacer 1379: 7 / 23, Sezgin 1991: 1/3/395). Bezzâr'ın Müsned'inde geçtiği şekliyle Hz. Ali, oğlu İbnü'lHanefiyye'yi, ferâize dair meselelerin olduğu bir sahife ile Hz. Osman'a göndermiş ve burada yazılı olanların Hz. Peygamber'in ferâize dair uygulamalarıdır, demesini istemiştir (Bezzâr 2009: 2 / 245).

Sezgin yine bu döneme ait Sa'd b. Ubâde'nin (öl. 15 / 636) bir kitabından bahsedildiğini bildirmektedir. Buna göre $\mathrm{Sa}^{\text {'d }}$ 'ın oğullarından biri, Hz. Peygamber'in hukukî uygulamalarını bu risaleden rivayet etmektedir (Sezgin 1991: 1/3/395). Biz kaynaklarda bu bilgiyi teyit edemedik.

Sezgin'e göre pek çok rivayet, sahabe neslinde fikhî meseleler hakkında yazışmanın yaygın olduğuna işaret etmektedir. Örneğin Nâfi ${ }^{*}$ b. el-Ezrak (öl. 65 / 685), Abdullah b. Abbâs'a (öl. 68 / 687-88), akrabaların miras payı ve çocuk cinayeti hakkındaki görüşünü sormak için bir mektup yazmıştır (bkz. İbn Ebî Hâtim 2006: 3 / 346).

Sezgin, bunun benzeri rivayetlerde zikredilen ve büyük ihtimalle sadece birkaç yapraktan oluşan bu kayıtların izlerinin, hadis derlemelerinde sürülebileceğini söyler. Ona göre bu risalelerde bulunan verilerin, hicri II ve III. asırda telif edilen salt hukuk kitaplarında ne kadar kullanıldığı ise hâlâ araştırmaya muhtaç bir konudur (Sezgin 1991: 1/3/395). Fakat şu kadarını söyleyebiliriz ki, özellikle Hz. Peygamber'in vefatının ardından, civar kabilelerde sadaka (zekât) hakkında gösterilen gevşeklik dolayısıyla, bu türden risalelerde zekât konuları, detaylarıyla anlatılmış ve bu veriler, hicri II. asırdan itibaren sistematik hukuk eserlerine işlenmiştir.

Sezgin'in bu dönem fikıh yazmaları arasında anılmaya değer kabul ettiği bir başka risale de Hz. Ömer'in (öl. 23 / 644), Ebû Musâ elEş‘arî (öl. 42 / 662-63) ile Muâviye’ye (öl. 60 / 680) yargılama hukuku 
hakkındaki gönderdiği mektuplardır (Vekî‘ 1947: 1 / 70-73). Ebû Musâ el-Eşârî'nin Hz. Ömer'e gönderdiği mektuplar arasında, müslüman tüccarların gayr-i müslim topraklara gittikleri zaman kendilerinden vergi alındığını, gayr-i müslimlerin de İslam topraklarına girdiklerinde vergi alınıp alınmayacağını sorduğu mektup da hukukî içerikli mektuplardan kabul edilebilir. Bu mektubun tamamına eş-Şeybânî'nin el-Hucce alâ ehl-i Medine adlı eserinde ulaşılabilir (Sezgin 1991: 1/3/395; Şeybânî 1403: 1/ 557).

Sezgin, zikredilen bu metinlerin, müstakil fikhî eserlerden ziyade, yazılı olarak kaydedilmiş hukukî emirler, mektuplar ve fikhî belgeler olarak nitelenmesinin gerektiğini söyler. Ona göre gerçek anlamda ilk fikhî çalışmalar, toplama ve derleme yoluyla ortaya çıkan çalışmalar olup bunların müellifleri, öncelikle Hz. Peygamber'in genç ashabı arasında aranmalıdır (Sezgin 1991: 1/3/395). Zira I. asrın sonlarına kadar yaşayan bu genç sahabelerin, kendilerinden önce derlenmiş metinlere ulaşmaları nispeten daha kolay olduğu düşünülebilir. Bu hususta Mısırlı tarihçi İbn Yunus (öl. 347 / 958), çok dikkat çekici bir örnek zikretmektedir: Abdullah b. Amr. b. el-As'ın, Huseyin b. Şufey b. Mâti‘ el-Asbahî (öl. 129 / 746) adlı talebesi, Mısır'da ona ait iki kitap rivayet etmiştir. Bunlardan biri "Kadâ Resülillâh fî kezâ ve kâle Resülullâh kezâ", diğeri ise "Mâ yekünu min el-ehdâs ilâ yevmi'l-klyâme" adını taşımaktaydı (Sezgin 1991: 1/3/395; Makrizî, el-Mevâ'iz: 2 / 332).

Sezgin'e göre erken dönemin en önemli fukahasından addedilen Zeyd b. Sâbit'in de (öl. 45 / 665 [?]) bu tür monografiler oluşturduğu anlaşılmaktadır. Ondan yapılan en önemli atıflar ise ferâiz meseleleri hakkındadır. Bu da onun bu konu hakkında bir risale yazdığını kuvvetle muhtemel işaret etmektedir. Medine'nin çok önemli fakihlerinden ve ayrıca talebesi Kabîsa b. Züeyb (öl. 86 / 705), ondan H VI. asırda hâlâ tedavülde olan Ferâiz'i rivayet etmiştir (bkz. Ahmed b. Hanbel 1422: 2 / 65). Mâlik ve eş-Şâfiî kendi eserlerinde bu ferâiz metnini esas almışlardır (Sezgin 1991: 1/3/396). Hadis kitaplarındaki ferâize dair 
meselelerin ravileri arasında Kabîsa'nın sılılıkla görülmesi Sezgin'in tezini güçlendirmektedir.

Yine Sezgin'in tespitlerine göre Zeyd b. Sâbit'in eserinden yapılan alıntılar Beyhakî’nin (öl. 458 / 1066) Sünen'inin miras hukuku bölümünde günümüze kadar gelmiştir. Beyhakî burada, Zeyd b. Sâbit' in istisnaî konumu ve Kitâbu'l-Ferâiz'ine, "Ferâiz ilminde Zeyd b. Sâbit'in sözünün diğer sahabelere tercih edilmesi" isimli bir alt başlik tahsis etmiştir (Beyhakî 20036 / 345). Rivayetlerden anlaşıldığına göre Zeyd b. Sâbit'in bu çalışması, miras hukuku alanında tâbiîn için bile vazgeçilmez bir kaynak teşkil etmiştir (Sezgin 1991: 1/3/396). Ayrıca bu eserin henüz erken bir dönemde, hem de devrinin önemli fakihlerinden sayılan Ebü'z-Zînad (Abdullâh b. Zekvân) (öl. 131 / 748) tarafından şerh edilmiş olması, eserin değerini göstermektedir (Sezgin 1991: 1/3/396). Nakledildiğine göre Ebu'z-Zinâd'ın oğlu Abdurrahman, babasının bu risaleyi Zeyd b. Sâbit'in büyük oğullarından Hârice b. Zeyd b. Sâbit'ten edinmiştir. Risale Muâviye'ye gönderilmiş olup farkl1 durumlarda dedenin mirastan nasıl pay alacağından bahsetmektedir (Beyhakî 1991: 9 / 135).

Zeyd b. Sâbit'in, ferâiz ilmiyle alakalı bu eserinin yanında Ömer b. Abdülaziz'in (öl. 101 / 720) bilinmeyen bir sebepten dolayı yaktırdığ Kitâbun fî'd-diyât adlı bir eseri daha bulunmaktadır (Ahmed b. Hanbel 1422: 2 / 160).

Genç sahabelerden sonra tâbiînin orta tabakası da ilk fikıh monografileriyle ciddi surette meşgul olmuştur. Nitekim fetihler hakkındaki ilk eserlerin yanı sıra ilk tefsirler de bu döneme aittir. Tarihçi, fakih ve şiir bilgini olarak şöhret salan eş-Şabî'den (öl. 103 / 721 ) bu tür monografik eserler çokça nakledilmektedir. Mücâhid, "Ben, Şabî'nin es-Sadakât ve el-Ferâiz hakkında üç tomar metni dikte ederek yazdırdığını gördüm" demiştir (Ahmed b. Hanbel 1422: 2 / 296; Sezgin 1991: 1/3/396). Hatîb el-Bağdâdî, onun Kitâbu'l-ferâ'id ile elCirâhât'ını zikretmektedir. Onun naklettiği rivayetlere göre Şa'bî 
öldükten sonra geriye yalnız bu iki eseri kalmıştır (Hatîb 2001: 14: 148; Sezgin 1991: 1/3/397).

$\mathrm{Bu}$ döneme ait, belli bir konuya münhasır eserler arasında Dahhâk b. Muzâhim'in (öl. 105 / 723), talebesi Hüseyin b. Akîl'e dikte ettirdiği Menâsikü'l-Hacc'1 da zikredilebilir (İbn Abdilber 1994: 1 / 312; Sezgin 1991: 1/3/397).

Tabiin döneminin sonlarına doğru zikredilmeye değer bir kişi de, hadisleri Ömer b. Abdülazîz'in emriyle resmen tedvin eden Muhammed b. Şihab ez-Zührî'dir (öl. 124 / 742). Onun "Fetâvề'si üç hacimli cilt hâlinde Muhammed b. Nuh tarafından derlenmiştir (İbn Kayyim el-Cevziyye 1423: 1 / 112).

Belli bir konuya hasredilmeyip genel fikıh konularını ihtiva eden metinlerden biri de Hasan el-Basrî̀ye (öl. 110 / 728) nispet edilen "Fetâvi" dir. Onun bu eseri sonraki âlimler tarafindan kalın yedi cilt (esfâr) hâlinde fikıh baplarına göre tasnif edilmiştir (İbn Kayyim 1423: $1 / 112)$.

İbn Kayyim'in eserinde bahsettiği, sahabeden Abdullah b. Abbas'a nispet edilen "Fütyâ Abdullah b. Abbâs" adlı eseri Sezgin, o dönemde tedvin edilen bir eser olup olmadığı bilinmediği için zikretmemiştir. Bu eserin daha sonraları Ebû Bekir Muhammed b. Mûsâ b. Ya'kub tarafından yirmi cilt hâlinde toplandığı rivayet edilmiştir (İbn Kayyim 1423: 1 / 112). Eser bugün elimizde mevcut değildir.

Sezgin'in bu döneme ait fikıh yazmalarından biri olarak andığ ancak mahiyetini zikretmemekle birlikte "Bu türün bizce bilinen en eski kitabı, Mekhül b. Şehrâb'ın (öl. 112 / 730), es-Sünen fỉl-fikh'1dır" dediği eser (İbn Nedîm 1997: 1 / 279) muhtemelen Mâlik'in Muvatta'1 gibi olmalıdır. Kanaatimizce ona nispet edilen "Kitâbu'l-mesâili'l-fikhiyye" (Eyyüb Said Kaya 2003: 28 / 552-553) onun başka bir eseri değil, az önce zikredilen eserinin içeriğini ifade etmektedir. Sezgin'e göre Mekhûl'un Kitâbu'l-Hacc'1 da sonraki hukukçular tarafından bilinmekteydi (İbn Hacer el-Askalânî 1326: 8 / 178; Sezgin 1991: 1/3/398). 
Fıkhın oluşum döneminden hicri I. asrın sonlarına kadarki dönemde telif edilen ya da bilgisi bize ulaşan eserler genellikle sahifeler hâlinde metinlerdir. Bu dönemin sonlarına yaklaşıldığında ise daha hacimli eserlerin ortaya çıktığını görebiliyoruz. Ancak bu dönemden günümüze çok az kitap ulaşmıştır. Sezgin bu dönemde telif edilen eserlerden birinin de Süleym b. Kays el-Hilâlı̂'ye nispet edilen Kitâb olduğunu söyler (Sezgin 1991: 1/3/400). Günümüz Şî̂ düşüncesine kaynaklık eden, yazılı ilk Şiî metni olma özelliği taşıyan ve Kitâbu Süleym ismiyle bilinen (İbn Nedîm 1997: 275) bu eser, fikhî içerikten daha çok imameti ispat bağlamında kullanılan rivayetler ile Gadir Hum, Sakife meselesi, velayetin farziyeti, mehdi inanc1, şefaat ile ehl-i beyt etrafinda cereyan eden tarihi meseleleri muhtevidir (Akdoğan 2014: 1417).

Hz. Hüseyin'in torunu ve Zeydiyye mezhebinin imamı olan Zeyd b. Ali'nin pek çok eseri günümüze kadar ulaşmayı başarmıştır (Sezgin 1991: 1/3/315-326). Bu eserleri arasında fikıhla ilgili olan iki eseri bilinmektedir. Bunlardan biri, Zeydiyye mezhebinin temel kitab1 olan el-Mecmû 'dur. Zeyd b. Ali'den gelen rivayetleri ihtiva ettiğinden el-Müsned diye de anılır. Pek çok yazma nüshasının yanında Milano 1919; Kahire 1340; Beyrut 1386 / 1966 ve San'a 1422 / 2002 tarihli baskıları mevcuttur. Onun hac ve umre ibadetlerini konu alan Mensekü (Menâsikü)'l-hac ve ahkâmüh (âdâbüh) adlı eseri de Minhâcü'l-hâc ismiyle Bağdat'ta 1330; 1342 yıllarında basılmıştır (Kılıç 2008: 128130)

$\mathrm{Bu}$ son döneme ait Sezgin'in zikrettiği ve günümüze kadar ulaşan eserlerden biri de tâbiînin âlim ve müfessirlerinden Katâde b. Diâme es-Sedûsî'nin (öl. 117 / 735) Kitâbü'l-Menâsik adlı eseridir. Baskının yapılıp yapılmadığı hususunda bilgi sahibi olamadığımız bu eser, Şam Zâhiriyye Kütüphanesi'nde 41 / 12 no'lu mecmua içinde bulunmaktadır (Sezgin 1991: 1/3/400).

Sezgin, fıkhın tedvinini ele aldığı bu bölümden sonra fikıhla ilgili eser yazdığını tahmin ettiği bazı fakihlere yer verir. Biz de 
Sezgin'in biyografilerine yer verdiği bu isimlere kısaca değineceğiz. Zira Sezgin, bu isimlerden bazılarının fikha dair eserleri bulunmasa ve kaynaklarda zikredilmese dahi bir takım işaretler onların da kitap telif etme ihtimalini yüksek olduğunu düşünmektedir. Bu kısımda Sezgin'in daha önce eserleri hakkında bilgi verdiği müelliflerin ise sadece isimlerini zikretmekle yetineceğiz.

\section{a. Zeyd b. Sâbit b. ed-Dahhâk el-Ensârî.}

b. Şüreyh b. el-Hâris b. Kays el-Kindî el-Kûfî (öl. 80 / 699 [?]): Aslen Yemenli'dir. Hz. Peygamber'i görememiştir. Halife Ömer ve Osman dönemi ile Emevîler döneminde, Küfe'de daha sonra Basra'da kadılık görevlerinde bulunmuştur. Şüreyh, İslâm'ın erken döneminin en önemli fakihleri arasında sayılmıştır (İbn Kuteybe 1992: 1 / 433; Ebû Nu'aym 1974: 4 / 132-141). Sezgin'e göre Şüreyh'e nispet edilen bir eser bilinmemekle beraber Veki'e ait Ahbâru'l-Kudât adlı eserde onun görüşlerinin büyük bir kısmını bulmak mümkündür. Ayrıca Hz. Ömer'in Şüreyh'e yazmış olduğu bir mektubun yanı sıra Basra kadısı Ebû Musa el-Eş'arî’ye yazdığı mektup, İslam yargı hukukunun temelini teşkil etmektedir (Veki' 1947: 2: 189-190; Ebû Nu'aym 1974: 4: 136; Sezgin 1991: 1/3/402).

\section{c. Kabîsa b. Züeyb b. Halhale el-Huzâî (öl. 86 / 705 [?]): İsmi,} Hz. Peygamber'i gören ancak kendisiyle konuşamayan sahabe arasında zikredilir. Büyük sahabelerden, özellikle Zeyd b. Sabit'ten rivayette bulunmuştur. İttifakla ilk tabakanın çok önemli fakihlerindendir (İbn Sa'd 1990: 5 / 134; İbn Kuteybe 1992: 1 / 447). Kabîsa, kendi ferâiz kitabını Zeyd b. Sabit'ten rivayet etmiştir (Ahmed b. Hanbel 1991: 2 / 65; Sezgin 1991: 1/3/402).

ç. Ebû İmrân İbrâhîm b. Yezîd b. Esved en-Nehaî el-Kûfî (öl. 96 / 714): Tâbiîndendir. Hz. Âişe, Enes b. Mâlik ve büyük tâbiîinnden rivayette bulunmuştur. Hammâd b. Ebî Süleyman onun râvileri ve talebeleri arasında yer alır. Kûfe'nin en önemli fukahasından biriydi (Ebû Nu'aym 1974: 4 / 225). Başlıca kabul ettiği otorite, sahabe Abdullah b. Mesud'du. Sezgin'e göre Nehâi'ye ait herhangi bir fikıh 
metninin varlığ́ bilinmemektedir. Ancak o, Ebû Yusuf, eş-Şeybânî ve eş-Şâfî̂'nin kitaplarından Nehâî'ye ait birçok hukukî görüşün bulunması ve tebe-i tâbiîn dönemi sistematik yazım geleneğine büyük katkıları olmasından dolayı onu eser sahibi müellifler kategorisinde zikretmiştir (Sezgin 1991: 1/3/403).

\section{d. Mekhûl b. Ebî Müslim Şehrâb ed-Dımaşkî (öl. 112 / 730):} Sezgin'in fikıh yazımına önemli katkıları olduğun düşündüğü kişilerden biri de Mekhûl'dür. Tâbiînden olup Hz. Âişe, Ebû Hüreyre, Ubey b. $\mathrm{Ka}{ }^{\circ} \mathrm{b}$ ve başkalarından rivayette bulunmuştur. Pek çok hadis seyahatinde bulunmuş bir muhaddis ve zamanının en önemli fukahasından biridir (İbn Sa‘d 1990: 7 / 315; İbn Nedîm 1997: 227).

Sezgin'in tespitlerine göre ona nispet edilen ve fikhî konuları muhtevi olan Kitâbü's-Sünen fi'l-fikh'ı (el-Mesâil fîl-fikh) İbn Nedîm tarafından ele alınmıştır. Kitâbu'l-Hacc'ını ise talebesi Alâ' b. el-Hâris el-Hadramî (öl. 136 / 753) rivayet etmiştir (İbn Hacer 1326: 7 / 178). Kitaplarından çok sayıda cüz ve bölümleri, sonraki fıkıh kitaplarında, özellikle de Mâlik'in el-Muvatta'sı ile el-Müdevvene'de mevcut olduğu görülmektedir (Sezgin 1991: 1/3/404).

\section{e. Hammâd b. Ebî Süleymân el-Kûfî̀ (öl. 120 / 738):} Tâbiindendir. Enes b. Mâlik'in yanı sıra, İbrahim en-Nehâî, eş-Şa'bî, Saîd b. Cübeyr ve Saîd b. el-Müseyyeb'in de aralarında bulunduğu tabiinin büyüklerinden rivayette bulunmuştur. Küfe'de re'yi ilk kullananlardan biri olmuştur. Hocaları arasında İbrahim en-Nehâî ilk sırayı alır. En meşhur talebesi ise Ebû Hanîfe'dir (İbn Sa‘d 1990: 6 / 324).

Sezgin'e göre onun telif faaliyetleri hakkında bilgi bulunmamaktadır. Fakat zamanındaki telif sahibi müellifler gibi onun da telifte bulunduğu tahmin edilebilir. Sezgin'in bu düşüncesinin temelinde, Ebû Yusuf, Muhammed eş-Şeybânî, Şâfiî’nin ve Mâlik'in kitaplarındaki rey ekolüne dair rivayet ve atıfların, ismi zikredilmese de onun kitaplarına dayandığı kanaati bulunmaktadır (Sezgin 1991: 1/3/405). 
f. Bükeyr b. Abdillâh b. el-Eşecc el-Kureşî (öl. 120 / 737): Medîneli'dir ancak sonraları Mısır'da yaşamıştır. Tabiinin büyüklerinden rivayette bulunmuştur. Fakih ve muhaddistir. Sezgin'e göre Bükeyr'in bir fikıh risalesi bulunmaktadır ve Mâlik, onun bu risalesine el-Muvatta'da "an es-sika 'indehu an Bükeyr b. Abdillâh..." isnadıyla atıfta bulunmuştur (İbn Abdilber 2012: 1 / 494). Fakat bu ifadelerden onun bir kitabı olabileceğini çıkarmak güç görünmektedir. Ayrıca Sezgin'e göre Bükeyr'in bu risalesi el-Müdevvene müellifi Sahnûn (öl. 240 / 854) tarafından sıklıkla kullanılmıştır (Sezgin 1991: 1/3/405).

g. Ebu'z-Zinâd Abdullâh b. Zekvân el-Kureşî (öl. 130 / 748): Medineli tabiinin önemli hukukçularından biriydi. Bazı âlimlerin değerlendirmesine göre o, Rebîatürre'y'den (öl. 136 / 753 [?]) daha âlimdir (bkz. İbn Hacer 1326: 5 / 204 Ziriklî 2002: 4 / 217). Sezgin'in tespitlerine göre, İbn Hacer, onu bir fikıh kitabının müellifi olarak niteler. Mâlik'in el-Muvatta'sında ondan naklettiği elli dört hadis, muhtemelen Ebü'z-Zinâd'ın fikıh kitabına dayanır. Onun Tefsîr alâ ferâ'id Zeyd b. Sâbit adlı kitabının önemli sayıda parçası ve alıntıları, Beyhakî'nin es-Sünen el-Kübrâ'sında mevcuttur (Sezgin 1991: 1/3/405).

h. Zeyd b. Eslem el-Adevî el-Ömerî (öl. 136 / 754): Tâbiinden olup Hz. Âişe, Ebû Hüreyre ve Câbir b. Abdillâh ve başkalarından rivayette bulunmuştur. Medine'nin en önemli fukahasından biri olmanın yanı sira müfessirdir (İbn Sa‘d 1990: 3 / 356).

Sezgin'in ifadelerine göre Zeyd b. Eslem'e ait bir fikıh telifatının varlığı bilinmemektedir. Ancak onun da, zamanının diğer fukahası gibi en azından bir veya birden fazla telifinin olduğu kabul edilebilir. Nitekim sonraki kaynaklarda hem onun ismiyle iktibas edilen hem de ondan rivayet edilen görüşler, onun metinlerine istinad ediyor olmalıdır. Mâlik, eI-Muvatta'sında ondan elli bir rivayet nakleder (bkz. İbn Abdilberr Tecrîd 2012: 68-97). Buna ilave olarak İbn 'Abdilberr'in el-Muvatta'dan naklen "Merâsîl Zeyd b. Eslem an nefsihi" başlığ

Uludağ Üniversitesi Fen-Edebiyat Fakültesi Sosyal Bilimler Dergisi Uludağ University Faculty of Arts and Sciences Journal of Social Sciences

Cilt: 21 Sayı: 39 /Volume: 21 Issue: 39

975 
altında bir araya getirdiği kendi görüşleri mevcuttur (İbn Abdilber 2012: 94-97). Sezgin'e göre onun pek çok fikhî görüşünü, Tefsîr'inde bulmak mümkündür. $\mathrm{Bu}$ eser, Taberî'nin tefsirinde kısmen ya da tamamen mevcut olduğu anlaşılmaktadır (Sezgin 1991: 1/3/405).

\section{Rebîa b. Ebî Abdirrahmân el-Medenî et-Teymî (öl. 136 /} 753 [?]): Tâbiînden olup, Enes b. Mâlik ve büyük tâbiinden rivayette bulunmuştur. Re'y konusundaki derin vukufu sebebiyle, bir övgü ifadesi olarak kendisine "Rebîatü'r-re'y" denilmiştir. Mâlik onun en önemli talebeleri arasında yer alır (Hatîb 2001: 9 / 414).

Sezgin, İbn en-Nedîm'in el-Fihrist'inde, Rebîa'nın herhangi bir eserine yer vermediğini ancak hadis kaynaklarında ona yapılan atıflar sebebiyle en azından bir kitabının hicretin II. asrında fakihler arasında tedavülde olduğunu düşünür. Bunun sebebi ise el-Muvatta' ravilerinden Abdullah b. Vehb'in (öl. 197 / 813) Rebîa'nın rivayetlerinden önemli ölçüde istifade etmesidir ve görünüşe göre el-Müdevvene'de bu kitabın büyük bir bölümü mevcuttur (Sezgin 1991: 1/3/406).

\section{i. Yahyâ b. Saîd b. Kays en-Neccârî el-Hazrecî el-Ensârî (öl.} 143 / 760): Medineli bir tâbiîdir ve Enes b. Mâlik ile diğer büyük tâbiînden rivaytte bulunmuştur. En önemli Medineli hukukçulardan sayılan Yahyâ b. Saîd, Sevrî'ye göre, Medineliler tarafindan ezZührî'den bile daha önemli kabul edilmiştir (bkz. İbn Hacer 1326: 11 / 222).

Sezgin, Yahyâ b. Saîd'in fikıh telifatının mevcudiyeti hakkında fazla bir malumatın bulunmamasına rağmen onun çok sayıda görüşünün özellikle Mâlik'in el-Muvatta'1, Şâfiî̀'nin el-Ümm'ü ve Sahnûn'un elMüdevvene'sinde mevcut olduğunu kaydeder. Bu sebeple Sezgin'e göre onun da bir kitabının mevcut olması gerekir (Sezgin 1991: 1/3/407).

\section{Sonuç}

Hz. Peygamber'in vefatının ardından İslam'ın ilk asrı pek çok önemli hadiseye sahne olmuş, başta iktidar mücadeleleri olmak üzere itikadî anlamda firkalaşmanın da başlamasıyla belli bölgelerde derin 
ayrılıklar baş göstermiştir. Yaşanan bu olumsuz gelişmelere rağmen Hz. Peygamber'in mirasını devralan sahabe, sahip oldukları bilgi birikimini aktarmak için mühim gayretler göstermişlerdir. Bu itibarla başta hadis ve fikha dair materyaller sahabe kanalıyla tâbiîne aktarılmış, ancak bunun için kitabe yönteminden daha çok ders halkaları yoluyla şifahi yol tercih edilmiştir. Dolayısıyla bu döneme ait yazılı metinler sonraki asırlara nispeten daha az olmuştur. Fakat bu döneme ait fikhî yazılı verilerin hicri II. asra nispeten ender olmasının sebebi için ihmal değil; imkânların elvermeyişi ve tedvin için yeterli olanakların bulunmayışını söyleyebiliriz. Buna rağmen o dönemde yazılan fikhî eserlerin bir kısmı günümüze kadar müstakil olarak ulaşabilmiş, bir kısmı da hicri II. ve daha sonraki dönemlerde yazılan müstakil hadis ve fikıh müdevvenatı içinde korunabilmiştir. Bu noktada şunu ifade etmekte yarar olduğunu düşünüyorum: Sezgin'in İslam'ın ilk asrında telif edildiğine dair tespitlerini delillendirdiği kaynakların başında Mâlik b. Enes'in Muvatta'1 gelmektedir. Eser günümüze kadar ulaştığı için incelemek ve geçmişe dönük atıfları bulmak mümkün olabilmiştir. Ancak bu döneme ait hadis-fıkıh eksenli çalışmaları başka kaynaklarda da aramanın gerekliliği ortaya çıkmıştır. Örneğin Yemenli Muhaddis Abdürrezzak'ın el-Musannef'inin, fıkıh mezheplerinin teşekkülünden önceki çalışmaları ihtiva ettiği bilinmektedir. Ancak onun Şiî olduğu iddiası sebebiyle eseri yeteri ilgiyi görememiştir. Yine Ma'mer b. Râşid'in Yemen'de ilk eser tasnif eden ve o bölgede hadisleri ilk tedvin eden kişi olduğu belirtilmekte, el-Câmi ' adlı kitabı Mâlik'in el-Muvatta'ından daha önce yazıldığı kabul edilmektedir. Bu sebeple, özellikle hadis kaynaklarının fikhî yönden analiz edilerek İslam'ın ilk dönemlerine ait yazınsal faaliyetler hakkında daha fazla bilgiye ulaşılabileceğini tahmin edilmektedir. Çalışmanın, hicri ilk asır yazınsal faaliyetlerin derinlemesine araştırılması yönünde katkı sağlayacağını ümit ediyorum. 


\section{Kaynaklar}

Ahmed b. Hanbel (2001). el-Müsned. Thk: Şuayb el-Arnavut, Beyrut: Müessesetü'r-Risâle.

(1422). el- 'Ilel ve Marifetü'r-Ricâl. Riyad: Dâru'l-Hânî.

Akdoğan, Mehmet Nur (2014). "Kitâbu Süleym b. Kays ve Kaynaklık Değeri". Bitlis Eren Üniversitesi Sosyal Bilimler Dergisi, C. 3, S. 2, s. $1-22$.

Beyhakî, Ahmed b. Hüseyin (2003). es-Sünenü'l-Kübrâ. Thk: Muhammed Abdülkadir Atâ, Beyrut: Dâru'l-Kütübi'l-İlmiyye.

Kal'acî, Kahire: Dâru'l-Vefâ.

Bezzâr, Ebû Bekir Ahmed (2009). el-Bahru'z-Zehhâr Thk: Mahfuzu'Rahman Zeynullah, Medine: Mektebetü'l-Ulûm ve'l-Hikem.

Brockelmann, Carl (1937-1942). Supplementband. Leiden: E. J. Brill.

Ebû Nu'aym, Ahmed b. Abdullah (1974). Hilyetü'l-Evliyâ ve Tabakâtü'l-Asfiyâ. Misır: Dâru's-Saâdet.

Ebû Ubeyde Kâsım b. Sellâm. el-Emvâl. Thk: Halil Muhammed Herras. Beyrut: Dâru'l-Fikr.

Dârekutnî, Ebü’l-Hasen Alî (1985). el- 'Ilel. Riyad: Dâru Taybe.

Demir, Hilmi (1998). “Tedvin Dönemi ve Anlamın Kökeni”. Dini Araştırmalar, C. 1, S. 2, s. 137-163.

Goldziher, Ignaz (1967). Muhammedanische Studien. London: George Allen \& Unwin.

Hallâf, Abdülvehhab. Hulâsatü Târîhi't-Teşrîi'l-İslâmî. Kuveyt: Dâru'lKalem. 
Hatîb el-Bağdâdî, Ebû Bekir Ahmed (1417). Târihu Bağdat. Beyrut: Daru'l-Kütübi'l-İlmiyye.

Dâru'l-Garbi'l-İslâmî.

(2001). Tarîhu Bağdâd. Thk: Beşşar Avvâd. Beyrut: el-Kifâye fì Ilmi'r-rivâye. Thk: Ebû Abdullah Surkî. Medine: el-Mektebetü'l-İlmiyye.

İbn 'Abdilberr, Ebu Ömer (1994). Câmi ‘u Beyâni'l-İlm. Suud: Dâru İbnü'l-Cevzî.

(2012). Tecrîdü't-Temhîd (et-Tekassî limâ fìlMuvatta'). Kuveyt: Vizâretü'l-Evkâf.

İbn Ebî Hâtim er-Râzî (2006). el- 'Illel. Riyad: Metâbiu'l-Humeydî.

İbn Hacer el-Askalânî (1415). el-İsâbe fì Temyîzi's-Sahâbe. Thk: Adil Ahmed, Beyrut: Dâru'l-Kütübi'l-İlmiyye.

(1379). Fethu'l-Bârî. Beyrut: Dâru'l-Marife.

(1326). Tehzîbu't-Tehzîb. Hindistan: Matbaatü Dâiretü'l-

Meârif.

İbn Kayyim el-Cevziyye (1423). I'lâmu'l-Muvakkîn 'an Rabbi'lÂlemîn. Suudi Arabistan: Dâru İbnü'l-Cevzî.

İbn Kuteybe, Ebu Muhammed Abdullah (1992). el-Ma ârif. Thk: Servet Ukkâşe, Kahire: el-Heyetü'l-Misriyye el-Âmme.

İbn Nedîm, Ebu'l-Ferec Muhammed (1997). el-Fihrist. Thk: İbrahim Ramazan, Beyrut: Dâru'l-Marife.

İbn Sa'd, Ebû Abdullah Muhammed (1990). et-Tabakâtü'l-Kübrâ. Thk: Abdülkadir Atâ, Beyrut: Dâru'l-kütübi'l-İlmiyye.

İbn Zenceveyh, Ebû Ahmed Humeyd (1986). el-Emvâl. Thk: Şâkir Feyyaz, Suudi Arabistan: Merkezü'l-Melik el-Falsal.

Uludağ Üniversitesi Fen-Edebiyat Fakültesi Sosyal Bilimler Dergisi Uludağ University Faculty of Arts and Sciences Journal of Social Sciences Cilt: 21 Sayı: 39 / Volume: 21 Issue: 39 
Kâtip Çelebi (1941). Keşfü 'z-Zünûn. Bağdat: Mektebetü'l-Müsenna.

Kaya, Eyyüb Said (2003). "Mekhûl b. Ebû Müslim". TDV İslâm Ansiklopedisi, Ankara: Türkiye Diyanet Vakfı Yayınları, C. 28, s. 552553.

K1lıç, Muhammed Tayyib (2008). İslam Hukukunda Kanunlaştırma Olgusu. Doktora Tezi. Ankara: Ankara Üniversitesi.

Makrizî, Ahmed b. Ali. el-Mevâ 'iz ve'l-i 'tibâr bi-(fi) zikri'l-hitat ve'lâsâr. Beyrut: Dâru Sâder.

Serahsî, Ebû Bekir (2000). el-Mebsut. Beyrut: Dâru'l-Fikr.

Sezgin, Fuat (1991). Târîhu't-Türâsi'l-Arabî (GAS), Çev: Mahmud Fehmî Hicâzî, Riyad: Câmiatü el-İmam Muhammed b. Suud elİslamiyye.

İstanbul: İbrahim Horoz Basımevi.

Şeybânî, Muhammed b. Hasan (1403). el-Hucce. Beyrut: Alemu'lKütüb.

Sıddik Hasan Han el-Kannnevcî (1978). Ebcedü'l-Ulûm. Beyrut: Dâru'l-Kütübi'l-İlmiyye.

Vekî‘, Ebû Bekir Muhammed (1947). Ahbâru'l-Kudât. Thk: Mustafa Merâğî. Misır: Mektebetü Ticariyye Kübrâ.

Zehebî, Ebû Abdillâh Şemsüddîn (1985). Siyeru A 'âmi'n-Nübelâ'. Thk: Şuayb el-Arnavut. Beyrut: Müessesetü'r-Risâle.

Ziriklî, Hayrüddîn b. Mahmûd (2002). el-A‘lâm. Beyrut: Dâru'l-İlmi li'l-Melâyîn. 


\section{EXTENDED ABSTRACT}

It is a fact that we do not have much information about the written works of the early eras of Islam. Many reasons have been given to this question; why the works of codification have not been improved or done in that time span? If we look at the general acceptance, many excuses about the limitedness of the works of codification in the early era of Islam have been given. Above all that reasons, we can list the most obvious ones as follows; the transmission of information through oral ways caught more attention due to its benefits, the conflicts have not been quite obvious in that era, concerns about the disruptions of the books and the rarity of the written material. However, we still have access to the works of fiqh which made its way from the first period of Islam to today's world.

According to Sezgin, who claims that the written works of hadith and fiqh can be traced back to the early eras of Islam contrary to the general thought, written records regarding the issues of fiqh have been present even in the era of Prophet Muhammad and his companions. For example; when the Emevi Caliph Umar b. Abd al-Azîz (d. 101 / 720) took the duty of caliphate, he sent someone to Mecca to find the work called Kitâbu's-Sadâkat which is about the aim properties and their percentages and these have been written by the order of Prophet Muhammad, and the work of Umar $b$. Hattab which has the same title. These two works have been finally found in the house of Amr b. Hazm Al-Hazrecî (d. 53 / 673). Umar b. Abd Al-Azîz gave an order to own copies of both of the works. These texts can be found in the detailed fiqh books which have been composed in the later eras. It is narrated as another example that Anas b. Malik took the letter which carries the orders of Prophet Muhammad regarding feraîz and charity from the Caliph Abu Bakr.

The general subject-matters of the sahifas and risâlahs which have been narrated to be written in the era of Prophet Muhammad and his companions are alms and their percentages and they carry lots of numerical information. After the death of Prophet Muhammad, issues regarding alms have been explained in detail in the risâlahs due to the looseness of the nearby tribes in terms of charity (alms). Also, the data about the inheritance law which requires a specialization has been written and created in the forms of risâlah in this period. Caliph Umar (d. 23 / 644) sent letters to Abu Musa al-Ashari (d. 42 / 662-663) and Muaviyyah (d. 60 / 680) regarding the issues of administrative law and judicial law, and this can be considered as one of the literary activities of the era. Sezgin claims that the texts that are known to be written in the era of the Companions should be considered as legal orders, letters, and files about the issues of figh rather than separate works of fiqh. According to him, the first fiqh studies in the real sense are the works that are created through gathering and 
composing. We should look for the authors of them in the young companions of Prophet Muhammad. For, we can think that these young companions who lived until the end of the first century had relatively easier access to the pre-composed works. At the end of the century, they started to create works that are thicker and exclusive to a certain issue.

For example; the work called Menâsikü'l Hajj which is dictated by Dahhak b. Muzâhim (d. 105 / 723) to his student Hussein b. Akîl, Fetâvi by Muhammad b. Şihab Ez-Zührî, the work called Fetâvi which is attributed to Hasan Al-Basrî (d. 110 1728) and Kitâbu'l Menâsik which is written by Katâde b. Diâme Es- Sedûsi (d. 117 I 735).These works are worth mentioning. Among the works that Sezgin gave proof to prove his determination that they are written in the first century of Islam, "Muvatta" by Malik $b$. Anas is the most important. It is possible to examine the work and find the retroactive references because the work has reached the present day. However, the necessity to look for works of hadith and fiqh of this period in other sources has appeared. Because of this, it is anticipated that we can find more information about the literary activities of the early eras of Islam through examining especially the work of hadith in terms of fiqh. 